\title{
Palatalization in the Russian verb system: a psycholinguistic study ${ }^{1}$
}

\author{
Elena Kulinich $^{1,2}$, Phaedra Royle ${ }^{2,3}$, and Daniel Valois ${ }^{1,2,4}$ \\ ${ }^{1}$ Department of Linguistics, Université de Montréal \\ ${ }^{2}$ CRBLM-Centre for Research on Brain, Language and Music \\ ${ }^{3}$ École d'orthophonie et d'audiologie, Université de Montréal \\ ${ }^{4}$ ISC-Institut des Sciences Cognitives, UQÀM
}

\begin{abstract}
In this paper, we present experimental data on the processing of loanwords and nonce words that focuses on morphonological alternations in Russian. This study addresses the issue of how stem allomorphy involving palatalization of the velar/palatal and dental/palatal types in the Russian verb system is processed in adults. Processing of morphonological alternations is shown to be quite variable (and probably unproductive) and to depend, on the one hand, on the distribution of allomorphs within the verb paradigm, and on the other hand, on verb class productivity. We hypothesize that these differences should be reflected in child language acquisition.
\end{abstract}

\section{Introduction}

Russian verbs are traditionally divided into two conjugation groups, $1^{\text {st }}$ and $2^{\text {nd }}$, based on their non-past inflectional pattern: verbs from the first conjugation group pattern with a thematic $-e$ (or -o- when stressed) in the non-past (e.g., čitaj-e-š (2sg.), čitaj-e-t (3sg.), čitaj-e-m (1pl.), 'read'), and those from the second conjugation group with a thematic - $i$ - vowel in the non-past (e.g., vid-i-̌s (2sg.), vid-i-t (3sg.), vid-i-m (1pl.), 'see'). Stem correlations involving morphonological alternations or other differences (e.g., alternating suffixes: ris- $O V$ - 'draw, past vs. ris- $U J$ - 'draw', non-past; tolk-NU- 'push', past vs. tolk- $N$ - 'push', non-past, etc.) define a variety of subclasses within these two main groups. These subclasses are heterogeneous and of variable membership: there are twenty four verb subclasses in the Russian verb system according to Jakobson's (1948) and Townsend's (1975) classifications, twenty subclasses according to Švedova (1980), and sixteen in Zalizniak (1977, 2003) ${ }^{2}$. Jakobson's and Townsend's classifications are based on one longer stem from which other stems are derived by a final vowel, or consonant, deletion rule. In this tradition, verbs are classified according to the stem type (e.g., $-a j-,-i-,-a-$, etc.). Švedova's and Zalizniak's classifications are based on stem relations and usually reflect correlations between past and non-past forms. For example, $-a j$ verbs (e.g., čitat' 'to read') are defined as verbs with an aj/a "relation" in Švedova (1980) and as verbs ending in -at' 'inf.', -aju 'non-past-1sg.', and -ajet 'non-past-3sg.' in Zalizniak (2003).

Stem correlations sometimes involve what we call palatalization, which applies to stems ending in velar or dental consonants (see Tables 1 and 2). However, not all stems of this kind

\footnotetext{
${ }^{1}$ The authors would like to thank the associate editor and three anonymous JSL reviewers for useful comments and suggestions. Any remaining errors are ours.

${ }^{2}$ These Russian verb classifications were recently compared by Slioussar (2003) who emphasizes her preference for Jakobson's as well as Townsend's classifications for psycholinguistic studies. We also use Jakobson's classification in this paper. For example, the verb citat' 'to read', will be described as an-aj-verb, xodit' 'to walk' as an - $i$ - verb, and plakat' 'to cry' as an - $a$ - verb.
} 
are subject to this type of palatalization: the stem correlation of the most productive Russian verb class (Jakobson's - aj- class) does not involve morphonological alternations that result in consonant mutations (e.g., čita-l 'read-past' - čitaj- $u$ 'read-1sg. non-past'). Thus, past stems ending in velar $(/ \mathrm{k} /, / \mathrm{g} /, / \mathrm{x} /)$ or dental $(/ \mathrm{t} /, / \mathrm{d} /, / \mathrm{s} /, / \mathrm{z} /)$ consonants theoretically have two possibilities in the non-past: the consonant either remains constant or undergoes palatalization (see Table 1).

Table 1. Past to non-past stem correlations in Russian for - at' infinitives

\begin{tabular}{|c|c|c|c|c|}
\hline \multicolumn{3}{|c|}{ Past (infinitive) } & \multicolumn{2}{|c|}{ Non-past (1sg.) } \\
\hline & $\begin{array}{l}x m y[\mathrm{k}] a t^{\prime} \\
x n y[\mathrm{k}] a t^{\prime}\end{array}$ & $\begin{array}{l}\text { 'to harrumph' } \\
\text { 'to whine' }\end{array}$ & & $\begin{array}{l}x m y[\mathrm{k}] a j u \\
x n y[\check{\mathrm{c}}] u\end{array}$ \\
\hline$Y$ & $\begin{array}{l}\breve{c i}[\mathrm{x}] a t^{\prime} \\
p a[\mathrm{x}] a t^{\prime}\end{array}$ & $\begin{array}{l}\text { 'to sneeze' } \\
\text { 'to plow' }\end{array}$ & $\begin{array}{l}X \\
\check{s}\end{array}$ & $\begin{array}{l}\check{c} i[\mathrm{x}] a j u \\
p a[\check{\mathrm{S}}] u\end{array}$ \\
\hline & $\begin{array}{l}\text { bro }[\mathrm{s}] a t^{\prime} \\
\text { pi }[\mathrm{s}] a t^{\prime}\end{array}$ & $\begin{array}{l}\text { 'to throw' } \\
\text { 'to write' }\end{array}$ & $\begin{array}{l}\mathrm{S} \\
\text { s }\end{array}$ & $\begin{array}{l}\text { bro[s]aju } \\
\operatorname{pi}[\text { š }] u\end{array}$ \\
\hline & $\begin{array}{l}\text { sle }[\mathrm{z}] a t^{\prime} \\
\text { ska[z]at }\end{array}$ & $\begin{array}{l}\text { 'to climb down' } \\
\text { 'to tell' }\end{array}$ & $\begin{array}{l}\mathrm{Z} \\
\check{Z}\end{array}$ & $\begin{array}{l}\text { sle }[\mathrm{z}] a j u \\
\text { ska[ž]u }\end{array}$ \\
\hline & $\begin{array}{l}s v a[\mathrm{t}] a t^{\prime} \\
\operatorname{prja}[\mathrm{t}] a t^{\prime}\end{array}$ & $\begin{array}{l}\text { 'to match' } \\
\text { 'to hide' }\end{array}$ & $\begin{array}{l}\mathrm{t} \\
\check{c}\end{array}$ & $\begin{array}{l}\text { sva[t] }] a j u \\
\operatorname{prja}[\check{c}] u\end{array}$ \\
\hline
\end{tabular}

Looking at stem correlations in the direction from the non-past to the past forms (Table 2), we observe that there are 2 or 3 potential outputs for stems ending in palatal in the non-past. Past stems either have a palatal consonant (and hence no alternation in this case as in mol[č $] u-$ mol[č $] a t$ ' 'to be silent') or a non-palatal consonant and show an alternation as in pla[č $] u$ pla $[\mathrm{k}] a t$ ' 'to cry', or prja[č $] u$ - prja $[\mathrm{t}] a t$ ' 'to hide'. It is clear that palatalization patterns in the Russian verb system, illustrated in Tables 1 and 2, are not transparent.

Table 2. Non-past to past stem correlations in Russian for -at' infinitives

\begin{tabular}{|c|c|c|}
\hline Non-past (1sg.) & Past (infinitive & \\
\hline $\begin{array}{ll}\check{\mathrm{c}} & \operatorname{pla}[\check{\mathrm{c}}] u \\
& \operatorname{mol}[\check{\mathrm{c}}] u \\
& \operatorname{prja}[\mathrm{c}[\mathrm{c}] u\end{array}$ & $\begin{array}{ll}\mathrm{k} & \text { pla }[\mathrm{k}] a t^{\prime} \\
\text { c } & m o l[\check{\mathrm{c}}] a t^{\prime} \\
\mathrm{t} & \text { prja }[\mathrm{t}] a t^{\prime}\end{array}$ & $\begin{array}{l}\text { 'to cry' } \\
\text { 'to be silent' } \\
\text { 'to hide' }\end{array}$ \\
\hline $\begin{array}{ll}\text { š } & p a[\check{\mathrm{s}}] u \\
& d y[\mathrm{~s}] u\end{array}$ & $\begin{array}{ll}\mathrm{x} & p a[\mathrm{x}] a t^{\prime} \\
\check{\mathrm{S}} & d y[\check{\mathrm{s}}] a t^{\prime}\end{array}$ & $\begin{array}{l}\text { 'to plow' } \\
\text { 'to breathe }\end{array}$ \\
\hline $\begin{array}{ll}\check{\mathrm{z}} & s k a[\mathrm{z}] u \\
& \operatorname{der}[\check{\mathrm{z}}] u\end{array}$ & $\begin{array}{ll}\mathrm{z} & s k a[\mathrm{z}] a t^{\prime} \\
\check{\mathrm{Z}} & \operatorname{der}[\mathrm{z}] a t^{\prime}\end{array}$ & $\begin{array}{l}\text { 'to tell' } \\
\text { 'to hold' }\end{array}$ \\
\hline
\end{tabular}

There are two types of palatalization in Russian: the first involves an automatic phonological process of consonant modification, for example, /d/ becomes $\left[\mathrm{d}^{\mathrm{j}}\right], / \mathrm{s} /$ becomes $\left[\mathrm{s}^{\mathrm{j}}\right]$ before $/ \mathrm{j} /$ or front vowels. The second, sometimes called consonant mutation, which is no longer phonologically conditioned, has resulted in morphonological alternations such as $/ \mathrm{d} / \sim / \check{\mathbf{z}} /, / \mathrm{s} / \sim / \check{\mathrm{s}} /$, 
etc. We focus on this second type of alternation and refer to it as palatalization here. For convenience the phonemes $/ \check{s}, \check{z}$, č/ are called "palatals". When describing stems with these phonemes, we use the term 'palatalized stem'.

In this paper, we examine palatalization in two different morphological contexts: a) in past/non-past stem allomorphy of a sub-group of Russian - $a$-verbs, and b) in a sub-group of $-i$ verbs where only the $1 \mathrm{sg}$. non-past has a palatalized stem allomorph (see examples in Tables 4 and 5 below). The palatalization possibilities are not the same in the two types of verb paradigms tested. The $-a$ - verb palatalization pattern involves velars but the $-i$ - stem verbs do not. In addition, -a- and - $i$ - verbs contain alternations in labials such as $/ \mathrm{b} / \sim / \mathrm{bl} /, / \mathrm{p} / \sim / \mathrm{pl} /, / \mathrm{v} / \sim / \mathrm{vl} /$, etc., under the same morphological conditions as dentals in each verb class ${ }^{3}$. These are not tested in our study because we are interested in alternations with palatal consonants such as $/ \check{s}, \check{z}$, č/ which occur with velars and dentals (see Table 3 ).

Table 3. Morphonological alternations in $-a$ - and $-i$ - stem verbs.

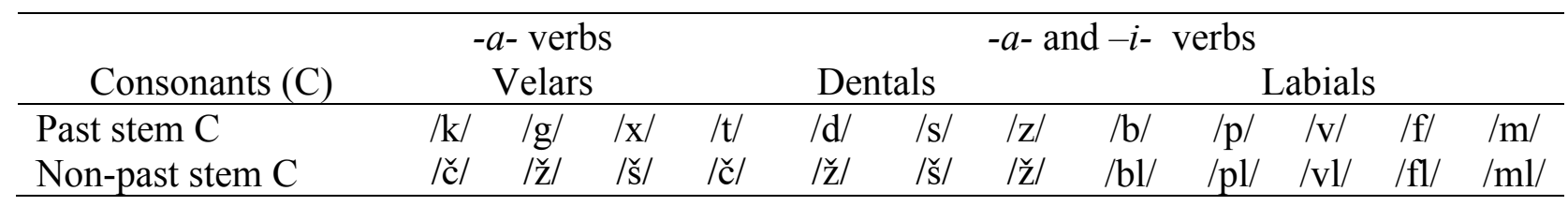

Because the morphonological alternation results in alternating stem forms, specific questions related to their representation and processing arise: 1) how many representations must be stored in the speaker's mental lexicon (i.e., is there only one underlying stem, or are all surface forms represented?), 2) if only the underlying stem is represented, how is it related to the surface forms?

There are different theoretical approaches to the interaction between morphology and phonology, the main ones being:

a) Phonological alternations. Surface representations are derived from an underlying representation via the application of phonological rules. Only the underlying form is stored in the lexicon (e.g., Chomsky and Halle 1968).

b) Allomorphic variation. In line with the exemplar-based models (e.g., Bybee 1995, 2001), all allomorphs are stored in the lexicon (see also Anderson 1992).

c) Mixed approaches. Both rule-based and exemplar-based processing can apply (e.g., Marcus et al. 1992; Pinker 1999, Bertram, Schreuder and Baayen 2000; see also Royle, Beritognolo and Bergeron 2012).

As some morphonological alternations can be predictable, it is often assumed that there is one underlying stem from which related forms are derived. For example, in Dutch voice/voiceless alternation leads to singular-plural allomorphy when the noun stem is combined with the plural -en suffix as in [bet] bed 'bed' - [bedən] bedden 'beds' (e.g., Zamuner, Kerkhoff and Fikkert 2012). The voiced consonant is considered to be the underlying one, and a process of devoicing applies when this consonant occurs world-finally. However, palatalization in Russian has

\footnotetext{
${ }^{3}$ Alternations in labials for $-a$ - stem verbs are limited to a few examples such as dremat' 'to doze', trepat' 'to scutch' and shipat' 'to pinch'.
} 
become less (or un-) productive as a result of historical change, and its degree of predictability depends on linguistic generalizations that speakers can make from their representations. Since several types of relationships can be established between morphologically related words, we predict that speakers should make different generalizations. In this work we study palatalization only in the inflectional verb paradigm, which shows at least two different patterns of palatalization.

(1) In all non-past forms of some particular inflectional paradigms ( - $a$ - verbs, see Table 4);

(2) In ONLY the $1 \mathrm{sg}$. non-past form of some other verb paradigms (-i-verbs, see Table 5).

Table 4. Palatalization throughout the non-past subparadigm in - $a$ - stem verbs: plakat' 'to cry'

\begin{tabular}{ll}
\hline Past & Non-past \\
\hline plak-al (masc. sg.) & plač-u (1sg.) \\
plak-ala (fem. sg.) & plač-eš (2sg.) \\
plak-alo (neut. sg.) & plač-et (3sg.) \\
plak-ali (pl.) & plač-em (1pl.) \\
& plač-ete (2pl.) \\
& plač-ut (3pl.) \\
\hline
\end{tabular}

Table 5. Palatalization only in the $1 \mathrm{sg}$. of the non-past subparadigm in $-i$ - stem verbs: $x o d i t^{\prime}$ 'to walk'

\begin{tabular}{ll}
\hline Past & Non-past \\
\hline xod-il (masc.sg.) & xo[̌̌]-u (1sg.) $\leftarrow$ \\
xod-ila (fem.sg.) & xod-iš (2sg.) \\
xod-ilo (neut.sg.) & xod-it (3sg.) \\
xod-ili (pl.) & xod-im (1pl.) \\
& xod-ite (2pl.) \\
& xod'-at (3pl.) \\
\hline
\end{tabular}

In Tables 4 and 5, the palatalized allomorph is linked to two different grammatical meanings: to the 'present' (non-past) in general (for the verb plakat' 'to cry') and to the ' $1 \mathrm{sg}$. non-past' (for the verb xodit' 'to walk'), respectively. Since these may represent different paradigm pressures with respect to the palatalized allomorph (see Hay and Baayen 2005 for the importance of relations between the whole and the parts in a paradigm), it is fair to ask whether the difference between these two allomorphy types could be reflected in verb production with one type of allomorphy possibly being processed more efficiently than the other one. For example, according to Bernštejn (1974), the 1sg. palatalized forms of verbs like xodit' 'to walk' tend to be replaced by non-palatalized forms (e.g., xod'u 'I walk') in some dialects of Russian, but these forms are protected from paradigm levelling by codification norms of standard Russian. This 
suggests that verbs of the type plakat' should be better mastered because of their consistent palatalization pattern, as compared to verbs like xodit' which only have one palatalized form in the paradigm.

However, this does not take into account verb-class productivity ${ }^{4}$. Verbs like xodit' are members of a productive $-i$ - verb class, while those like plakat are members of a nonproductive $-a$ - verb class (e.g., Slioussar 2003). So although xodit' only has one palatalized allomorph, the strength of its verb-class paradigm might protect it from levelling, while verbs like plakat' might be more susceptible to analogical pressure from the productive $-a j$ - verb class. If so, the question arises as to how novel and recently borrowed verbs will be integrated into these paradigms and whether palatalization in particular, will be robustly maintained.

It is difficult to predict which types of linguistic abstractions speakers can make from these and other verbs with respect to palatalization. Our intuition suggests rather specific (i.e., lexicalized) knowledge of verbs with palatalized/non-palatalized stem allomorphs. However, it is possible for Russian speakers to make generalizations about palatalization patterns related to different morphological contexts. More specifically, because of phonological similarity of $-i$ verb stems ending in dentals (Daland, Sims, and Pierrehumbert 2007), the alternation pattern as in $x o[\mathrm{~d}]-i l$ 'past, masc. sg.' - $x o[\check{z}]-u$ 'non-past, 1sg.' is predictable and expected to be extended to novel $-i$ - verbs, or to be productive (in the sense of Berko 1958). In both $-a$ - and $-i$ - verbs the palatalization is not an automatic phonological process.

We assume that palatalization productivity depends on verb class productivity and on the morphonological pattern involved in allomorphy within the verb paradigm. We also assume that for the palatalization of the - $a$ - verbs type (e.g., pla[k]-al 'past, masc. sg.' - pla[č ]- $u$ 'non-past, 1sg.') speakers should not systematically apply palatalization to nonce stems ending in dental or velar consonants because in standard Russian this palatalization applies to a limited class of -astem verbs, and they are in competition with the very productive $-a j$ - verb class which does not exhibit stem allomorphy.

The main questions are: Do Russian speakers make use of information about the distribution of palatalized vs. non-palatalized allomorphs within verb paradigms (e.g., whether the palatalized allomorph is present in only one or in many forms in the paradigm)? And if they do, do they take verb class productivity into account (e.g., is palatalization more productive in verbs within a more productive class)? Our hypotheses are: 1) If consistency within a verb paradigm is a more important factor than verb class productivity, then speakers will extend the palatalization pattern of the plakat' type to nonce or borrowed verbs more often than the palatalization pattern of xodit' type. 2) If it is verb class productivity that plays the more important role, then the palatalization pattern of the xodit' type (-i-verbs) will be more easily generalized than that of the plakat' type (- $a$ - verbs).

These hypotheses were tested using two palatalization experiments involving nonce- and loanwords. In order to exclude effects of analogical pressure from the productive - $a j$ - verbs, we also conducted a de-palatalization task (from the palatalized non-past form to the target non palatalized past). Here we expected that if speakers do make generalizations about the correspondence between dental or velar consonants and palatal consonants, they will alternate palatalized non-past stems with non-palatalized past stems. The next section provides

\footnotetext{
${ }^{4}$ Verb classes that serve as a conjugation model for new or borrowed verbs are taken to be productive. For example, many computer-related borrowings in Russian fall into - $i$ - verb class: apgrejdit' from 'to upgrade', xoldit' from 'to hold, etc. (see Table 6).
} 
experimental data from the three production tasks with adults. In the following sections the data are discussed in relation to our hypotheses and to the acquisition of morphophonology. We conclude in Section 5.

\section{Data}

In this section, we address two types of data that allow insight into the process of palatalization in Russian verb paradigms. First, we present results from two nonce-probe tasks on palatalization (of the type given in Table 3). As the two tasks test palatalization in two opposite directions, from non-palatalized to palatalized and from palatalized to non-palatalized allomorphs, we call them the palatalization task and the de-palatalization task, respectively. Second, we compare these results with data on the integration of computer-related loanwords ($i$ - verbs), whose paradigms also contain palatalized and non-palatalized allomorphs. In the nonce-probe tasks we study past / non-past stem correlations in verbs which would involve palatalization over the whole non-past inflection paradigm. In case of loanwords, only one form in the non-past paradigm (non-past, 1sg.) undergoes palatalization, while the stem allomorph of the other forms is not palatalized (as in $-a$-verbs). We think that it is useful to compare the data for nonce words and loanwords because these two kinds of stimuli are often used to test productivity of phonological or morphological processes.

\subsection{Nonce-probe task}

The aim of the written nonce-probe task (inspired by Berko's wug-test, 1958) was to test speakers' intuitive knowledge of palatalization, and more specifically, to understand whether morphological alternations are related to specific lexical entries or whether they can be applied to novel, or less well-known, words. In order to study this we created a list of 16 nonce verbs with stem final consonants that could potentially alternate with a palatal one. Nonce verbs were created mostly by modifying existing words by adding the infinitive suffix $-(a) t$ ' to monosyllabic (or disyllabic) names.

\subsubsection{Task 1: production of non-past forms for nonce verbs}

In this task adult-speakers' behavior was tested with respect to the application of palatalization in the non-past to nonce-verb stems ending in dental or velar consonants.

\subsubsection{Participants}

A group of 20 native speakers of Russian participated in a written production task. All participants were adults aged between 20 and 50 years $(M=39.85, S D=13.42)$. All participants were from Moscow, and all were speakers of standard Russian.

\subsubsection{Stimuli and procedure}

A list of 16 novel verbs (see Appendix) was created primarily by adding (C)at' to a real word. Some nonce verbs are not based on existing words but are similar to them (for example, the non -word fykat' is similar to fukat' 'to huff'). All resulting nonce words were disyllabic (snek 'snack' $\rightarrow$ snekat', muxa 'fly' $\rightarrow$ muxat', dva 'two' $\rightarrow$ dvasat') with stems ending in a velar or dental consonant. Thus, we controlled items for syllabicity (only disyllabic, 5-6 segment items were used in our experiment) and final consonant type (7 velar and 9 dental). We did not control 
stimuli for their stress pattern because we do not believe that stress is a primary factor in palatalization alternations.

Nonce verbs were presented in the infinitive form (e.g. snekat') to the participants, who were asked to produce corresponding $1 \mathrm{sg}$. non-past forms by filling out blanks on a page (i.e. Snekat'. Ja 'I' __). Given the behavior of the Russian verb paradigms illustrated above, for the nonce verb snekat', for instance, participants could be expected to produce either snekaju (without palatalization) or sneč (with palatalization). The experiment lasted 15 - 20 minutes.

\subsubsection{Results}

Speakers' responses were coded as having a palatalized vs. non-palatalized stem final consonant. For the analyses, the number of palatalizations and non-palatalizations was calculated for each subject and each item. Palatalization rates were quite low (much lower than chance).

Because of the distribution of responses, a nonparametric one-way chi-square analysis was run to compare the occurrence of both response types (palatalization vs. non-palatalization), with the within- factor consonant type (dental vs. velar). Non-palatalization occurred in the greater number of responses $(n=271)$, while palatalization occurred in the least number of responses $(\mathrm{n}=49), \chi^{2}(15, N=320)=154.01, p<.001$. Consonant type had no effect on palatalization rates $\left(\chi^{2}(15, N=320)=1.93, p=0.17\right)$.

We observed variability in palatalization rates across participants. Palatalization was applied in $15.31 \%$ of responses on average $(S D=6.4)$, but participants divided in two groups: palatalizing and non-palatalizing ones. Only 8 of the 20 participants produced palatalized allomorphs in the 1sg. non-past, and of these, only four applied it $50 \%$ of the time or more (see Figure 1 where palatalization rates are presented for each participant).

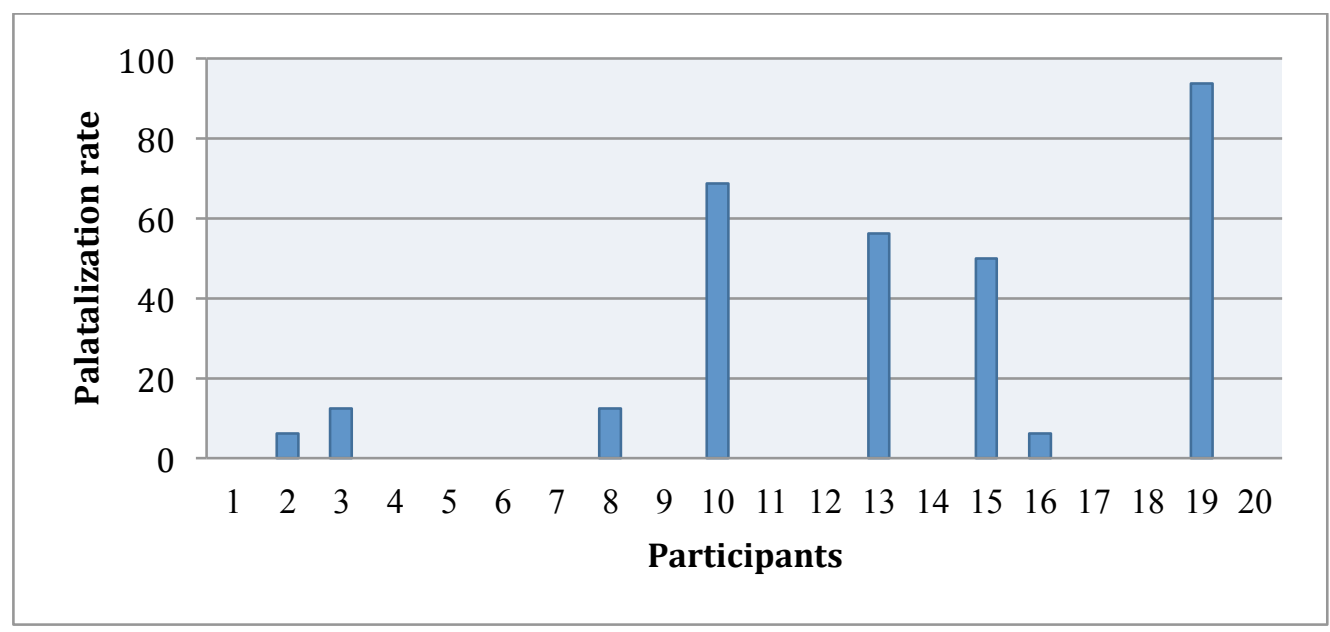

Figure 1. Percentage of palatalization by each participant in Task 1

\subsubsection{Task 2: production of the de-palatalized infinitive from 1sg. non-past of nonce verbs}

The aim of this task was to test speakers' intuition on palatalization but in the opposite direction: from the palatalized to the non-palatalized allomorph. This is based on the observation that some Russian verb paradigms have only one palatalized stem (without allomorphy as in molčat' 
'to be silent') within a paradigm, while others have palatalized/non-palatalized allomorphs elsewhere in the paradigm. Thus, as in the Task 1, there is choice and possibly variability in applying palatalization.

\subsubsection{Participants}

A group of 20 other native speakers of Russian participated in a task similar to the first one. All participants were adults aged between 17 to 74 years old $(M=40.8, S D=9.77)$ from Moscow who spoke standard Russian.

\subsubsection{Stimuli and Procedure}

Similar stimuli as in Task 1 were used in Task 2 but they were presented in the opposite direction: instead of producing the $1 \mathrm{sg}$. non-past from a given infinitive, the participants were asked to derive the infinitive from a given $1 \mathrm{sg}$. non-past form. The $1 \mathrm{sg}$. non-past form (e.g. $J a$ sneču) was presented to the participants, who were then asked to produce its corresponding infinitive form. The task lasted 15 to 20 minutes.

\subsubsection{Results}

Speakers' responses were coded as palatalized or non-palatalized. As in Task 1 there was variability in observed patterns. De-palatalization was applied in $28.7 \%(S D=8.75)$ of all produced forms. As in Task 1, participants divided in two groups: half the speakers applied the alternation and only 6 of these did it more than $50 \%$ of the time, while 10 never de-palatalized. (See Figure 2 where de-palatalization rates are presented for each participant). A one-way chisquare analysis was run to compare the two response types (de-palatalization vs. no-change). This revealed a statistically significant difference in the frequency of non-palatalized versus palatalized stem production, $\chi^{2}(15, N=320)=57.80, p<.001$. De-palatalization occurred in the least number of responses $(n=92)$, while palatalized stems underwent no change in a greater number of responses $(n=228)$.

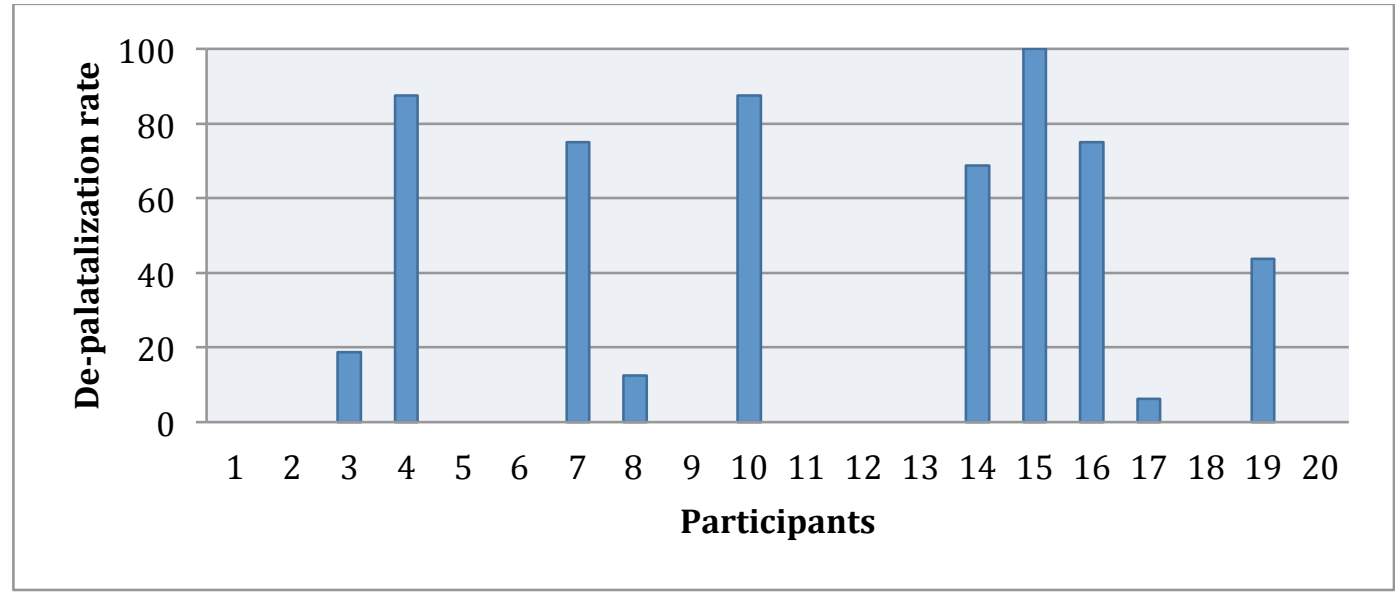

Figure 2. Percentage of de-palatalization by each participant in Task 2

\subsubsection{Discussion}


Results from both experiments show that, as expected, (de-)palatalization in Russian verbs is not fully productive. Nevertheless, the data suggest that these alternations may not be linked to specific lexical entries because they can occur with novel stems. However, if we observe the data in more detail, we can see that of 8 participants applying the alternation in Task 1 , only 4 do it systematically, while the other 4 participants do it occasionally. In Task 2, 6 of 10 participants are consistent in showing depalatalization more than $50 \%$ of the time, one does it less than $50 \%$ of the time, and 3 do it on less than $20 \%$ of produced forms. Even if not all participants applied the alternation (10 of 20 speakers did not do it at all) de-palatalization appears to be productive at least for some speakers. This inconsistency in the results leads us to another possible explanation: (de)palatalization could be chosen by some participants as a response strategy. In view of the absence of these types of responses in a good number of participants, our results do not support the notion that palatalization is a productive pattern in Russian. The results also show that there is more variability in terms of de-palatalization in Task 2 than there is with respect to palatalization in Task 1 (we will return to this result in section 3).

Speakers also sometimes make errors while applying palatalization: it seems that they have information about the presence of alternation but use this information in an innovative way, for instance by producing contaminated forms such as $m o[\check{s} \mathrm{c} c] u$ from $m o[s] a t^{\prime}{ }^{5}$ In Russian, /s/ alternates with /š/ but never with /šč/. In addition, the examples sme[č] $u$ from sme[x]at', illustrates a case where $/ \mathrm{x} /$ alternates with $/ \check{\mathrm{c}} /$. In Russian, $/ \mathrm{x} /$ alternates with $/ \check{\mathrm{s}} / \mathrm{but}$ never with $/ \check{\mathrm{c}} /$. Finally, examples such as $s n e[\check{\mathrm{s}}] u$ from $s n e[\mathrm{k}] a t^{\prime}, m o[\mathrm{k}] a t^{\prime}$ and $m u[\mathrm{k}] a t^{\prime}$ from $m o[\check{\mathrm{s}}] u$ illustrate cases where /k/ alternates with /š/, which also does not normally occur in Russian.

\subsection{Integration of new computer borrowings}

In this section, we address the second type of allomorphy found in $-i$ - verbs where the final dental of the stem undergoes palatalization in the $1 \mathrm{sg}$. non-past as in, for example, the verb $x o[\mathrm{~d}] i t$ ' 'to walk' - $x o[\check{z}] u$ 'I walk' $1 \mathrm{sg}$. non-past. For this study computer-related loanwords were used. Palatalization was tested in a similar written production task.

\subsubsection{Task}

In this task adult-speakers' behavior was tested with respect to the application of palatalization to loanwords ending in dentals.

\subsubsection{Participants}

23 native Russian speakers (average age 21 years, $S D=3.6$ ) participated in a production task involving computer-related loanwords verbs. All speakers were university students from Moscow and spoke standard Russian.

\subsubsection{Stimuli and Procedure}

The stimuli consisted of a list of verbs recently borrowed from English and used in computer related contexts (Table 6 ). All of them were 2 nd conjugation $-i$ - verbs and their stem-final dental could potentially alternate with a corresponding palatal in the $1 \mathrm{sg}$. non-past.

Participants were asked to derive the $1 \mathrm{sg}$. non-past from infinitives whose stem ended in dental consonant by filling in a blank in a written task. For example:

\footnotetext{
${ }^{5}$ For statistical analysis these forms were coded as palatalized.
} 
$J a($ apgrejdit') moj compjuter.

'I (to upgrade) my computer'

Table 6. Russian computer-related $-i$ - verb class loanwords used for Task 3

\begin{tabular}{|c|c|}
\hline Verb in Russian & Origin \\
\hline flud-i-t' & 'to flood' \\
\hline čat-i-t'-sja & 'to chat' \\
\hline konekt-i-t'-sja & 'to connect' \\
\hline otrout $-i-t^{\prime}$ & 'to route' \\
\hline frend-i- $t^{\prime}$ & 'to make friends' \\
\hline apgrejd-i-t $t^{\prime}$ & 'to upgrade' \\
\hline xold-i-t' & 'to hold' \\
\hline$f i k s-i-t^{\prime}$ & 'to fix' \\
\hline gejt-i-t' & 'to gate' \\
\hline
\end{tabular}

\subsubsection{Results}

As in the Task 1 and 2, speakers' responses were coded as palatalized or non-palatalized. The alternation was applied in $51.66 \%(S D=30.3)$ of the produced forms. Results show strong variability between items and between subjects, as evidenced by the large standard deviation. A nonparametric one-way chi-square analysis on frequencies for response types (palatalization vs. non-palatalization) did not reveal a statistically significant difference between these two response patterns, $\chi^{2}(22, N=207)=.237, p=.627$. Non-palatalization occurred in almost the same number of responses $(n=107,51.7 \%)$ as palatalization $(n=100,48.3 \%)$. Thus, the data appear to show that Russian speakers do not agree on the form for the 1sg. non-past of these verbs, and produce forms either with or without palatalized alternation (see Figure 3 where palatalization rates are presented for each participant).

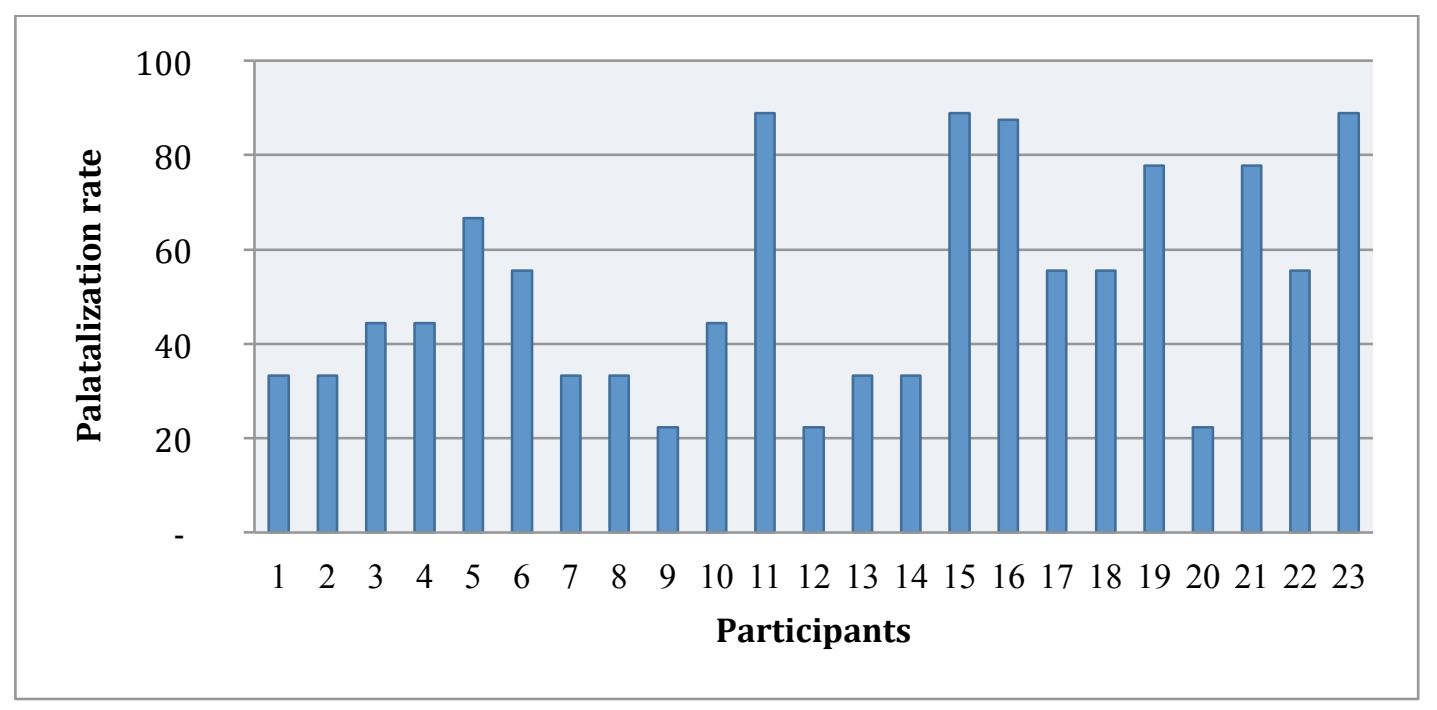


Figure 3. Percentage of palatalization on borrowings by each participant in Task 3

\subsection{Comparison of Task 1 and Task 2}

To determine whether there is a difference in applying morphonological alternations in presentfrom-past derivation versus past-from-present derivation, an unpaired t-test was conducted between results of Task 1 and 2 . A statistically significant difference was found $(p<.001)$, with Task 1 showing less palatalization $(15.31 \%, S D=6.44)$ and Task 2 showing more depalatalization $(28.99 \%, S D=8.75)$. This shows that speakers have a stronger tendency to derive non-palatalized stem allomorphs from palatalized ones than the reverse. In addition, as can be seen in Figure 4, this was the case for almost every individual nonce verb (except for verbs $b r u[\mathrm{k}] a t^{\prime}-b r u[\check{c}] u(6), s m e[\mathrm{x}] a t^{\prime}-s m e[\check{\mathrm{s}}] u(8)$, and $\breve{s} r e[\mathrm{k}] a t^{\prime}-\check{s} r e[\check{c}] u(14)$.

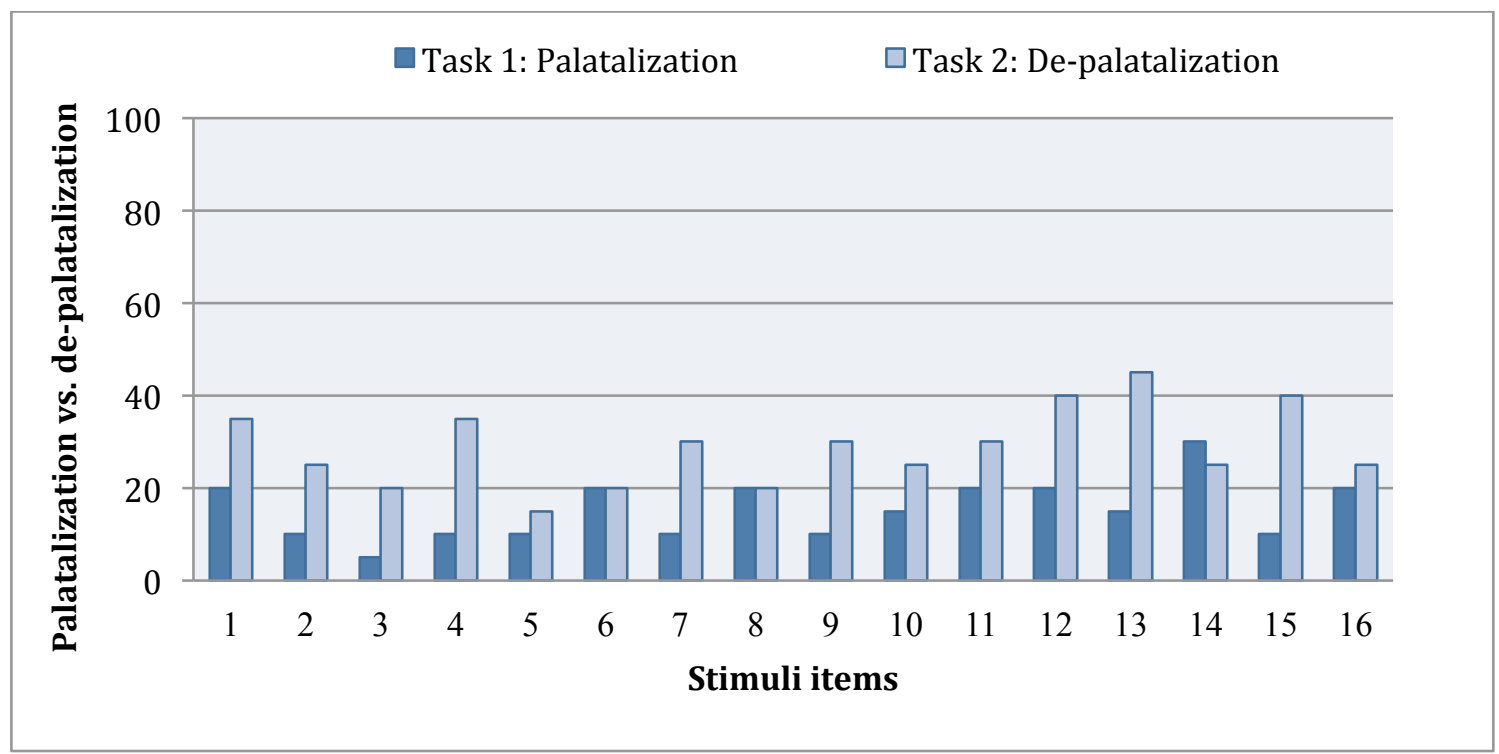

Figure 4. Percentage of palatalization in Task 1 vs. de-palatalization in Task 2 for each verb

\subsection{Comparison of Task 1 and Task 3}

In both these tasks the direction of change was from non-palatal to palatal stem but the test was on either allomorphy of type 1 (past/non-past) with nonce verbs, or allomorphy of type 2 (1sg. non past/other forms) with loanwords. To determine whether there was a difference in applying palatalization in both of these conditions, an unpaired t-test was conducted. Because of the different number of items in each task, an F-Test for homogeneity of variance was first done $(p$ $<.001)$. An unpaired t-test assuming non-homogeneity of variance showed statistically significant differences between the two types of allomorphy $(p<.001)$ with Task 1 , involving 
nonce verbs, showing significantly less palatalization $(M=15.31 \%, S D=6.44)$ than Task 3 , in which loanwords were used $(M=51.66 \%, S D=30.3)$.

\section{Discussion}

In section 2, we proposed that the same morphonological alternation that leads to palatalized/non-palatalized stem allomorphy is realized differently in different morphological conditions. We hypothesized that speakers can make different generalizations about palatalization that depend on the distribution of allomorphs within the verb paradigm and verb class productivity. Specifically, we hypothesized that two factors may influence the processing of palatalization: (i) consistency of palatalization within a verb paradigm - in this case the palatalization that applies in $-a$ - class verbs with past/non-past allomorph distribution throughout the paradigm should be more productive - , or (ii) verb class productivity - in this case the second type of allomorphy (in - $i$ - class verbs where only the $1 \mathrm{sg}$. non-past stem allomorph is palatalized) should be productive. Finally, we expected that (iii) for the first type of allomorphy, there would be a difference in applying (de-) palatalization in different directions: (1) from the non-palatalized past to the palatalized non-past stem, and (2) from the palatalized non-past to the non-palatalized past stem. De-palatalization was expected to apply more often than palatalization. We hypothesized that this difference could be related to analogical pressure from the most productive $-a j$ - verb class: in the palatalization task we expected analogical pressure from the productive $-a j$ - class (where there is no consonant alternation) to influence the application of palatalization, while the influence of $-a j$ - verbs is excluded in de-palatalization tasks.

Our results appear to have borne out our hypotheses. At first glance, both nonce verbs and loanwords show somewhat similar results: palatalization can be extended to both types of verbs. However, there is also an important difference between these two kinds of verbs. Participants of the two nonce-probe tasks divide almost completely into two groups: those who do not apply (de-)palatalizion processes and those who do. In addition, speakers who apply (de-) palatalization do it either consistently (more than $50 \%$ of time) or occasionally (less than $20 \%$ of time). These results suggest that some speakers have chosen palatalization as a response strategy rather than extending this alternation productively to nonce words. Furthermore, on average only $15 \%$ of forms were palatalized. This is clearly not evidence for a productive morphonological process.

There is even greater individual variability across subjects and across items in the task with loanwords. The comparison of Tasks 1 and 3 indicates that palatalization is more plausible in the condition where only the form of the $1 \mathrm{sg}$. non- past is palatalized in $-i$ - verbs than when palatalization applies to all non-past forms of $-a$-. This result was expected because $-i$ - verbs are a productive verb class in Russian. However, even under this condition only $51.66 \%$ of forms are palatalized on average. We thus observe that palatalization is not as consistent as would be expected, even in ideal conditions for its realization. In our opinion, this either suggests that loanwords are not fully integrated, and that the percentage of palatalization reflects instability of the integration process, or that pressure is exerted from the rest of the verb paradigm where all forms except the $1 \mathrm{sg}$. are non-palatalized. 
The comparison of the Tasks 1 and 2 shows that speakers de-palatalize more often (28.99\% of time) than they palatalize $(15.31 \%)$, i.e. they prefer to apply the alternation deriving a non-palatal allomorph from palatal one than when deriving a palatal allomorph from nonpalatal one. We explain this result rather simply: in Task 2 there is no influence from the productive $-a j$ - verb class on the output.

As discussed by Pierrehumbert (2006) in her study on velar softening in English (as in electri[k]-electri[s]ity), understanding the productivity of an alternation "provides a crucial line of evidence about [speakers'] cognitive abstractions". Thus, if an alternation fails to extend to non-attested forms, it suggests that speakers do not form any abstract generalization for this specific rule. If the alternation is "aggressively and reliably" extended, it means that a generalization has been formed. In addition, "if the situation lies somewhere in the middle, then the exact pattern of productivity can yield insights about the exact character of the abstraction that is formed" (Pierrehumbert 2006: 84-85). In Russian, it seems that palatalization represents an alternation that is neither completely unproductive, nor reliably productive. Furthermore, the same alternation seems to have different degrees of productivity depending on several factors, such as the nature of allomorph distribution within a given paradigm, verb class productivity or verb class interactions. Among these factors it seems that verb class productivity has more influence than allomorph distribution. The plakat type of allomorphy (- $a$ - verb class) is not productive, as these verbs constitute a limited class, and thus do not generalize to novel (nonce) verbs (e.g., snekat' - snekaju, not sneču) despite the fact that forms within the non-past paradigm all exhibit the palatalized allomorph. These verbs are apparently subject to word specific (and stem specific) learning, and thus, palatalization is not readily extended to novel or nonce verbs. However, the second type of allomorphy (observed in $-i$ - verbs e.g., xodit' 'to walk') is quite productive and therefore results in transfer to borrowings such as apgrejdit' 'to upgrade'. The reason for this is the more systematic application of palatalization in these verb paradigms: stems ending in dental consonants often palatalize in the $1 \mathrm{sg}$. non-past. The difference in applying (de-)palatalization in different directions: (1) from the non-palatalized past to the nonpast stem, and (2) from the palatalized non-past to the past stem can be explained by the presence (in palatalization Task 1) or absence (in de-palatalization Task 2) of the productive $a j$ - verb class influence.

\subsection{Possible limitations to our study}

Since our stimuli consisted in new borrowed or nonce verbs, we did not take into account lexical neighborhood effects and frequency that are undoubtedly important factors influencing lexical access and productivity. This issue needs to be addressed in further studies. However, even if the similarity of non-verbs to existing words of Russian in our study could influence results, we do not observe such effects in speakers' behavior. For instance, speakers who apply palatalization seem to apply it to more than $50 \%$ of nonce verbs, while most participants do not palatalize at all. These results are in line with other evidence that morphonological alternation productivity depends on type frequency and does not seem to depend on token frequency: "[...] alternations found in extremely few types [...] are not productive no matter how frequently the irregular forms may be used". (Pierrehumbert 2006:87). The palatalization pattern, whose productivity we test with nonce verbs is not related to high type frequency verbs ( $-a$ - verb class is unproductive) and thus the palatalization pattern is not reliably extended to nonce words. On the contrary, the palatalization pattern tested with borrowings falling into $-i$ - verb class appears to have been 
influenced by type frequency. Even if we observe item variability, the results suggest that speakers make a generalization about the alternation pattern involved.

Moreover, the productivity of some alternations may depend on word stress (as was shown for the vowel/zero alternation originated from the short vowel yer in the Gouskova and Becker's 2013 study), but in the case of palatalization the morphonological alternation was originally motivated by factors other than stress (i.e., front vowel or $/ \mathrm{j} /$ ). Thus, we would not expect to observe any strong effect of stress pattern on palatalization productivity in tested verbs. We cannot, however, completely exclude this factor as being irrelevant because it is possible that some Russian verbs classes are associated with a particular stress pattern, and we admit that if these verb classes are productive, stress placement can play a role in prompting some morphonological processes. According to Zalizniak (1985), there is no correlation between verb classes and stress patterns, but a recent study by Slioussar (2003) suggests that each verb class in Russian has a particular stress pattern combination. For example, - $a j$ - verbs have stress on the stem in past and non-past forms, while $-i$ - verbs have three combinations almost equally distributed among verbs of this class: 1) stress on the stem in past and non-past forms, 2) stress on the stem in past forms and on the inflection in non-past forms, and 3) stress on the stem in past forms and either on the stem or the inflection in non-past forms. As for $-a$ - verbs, they are equally distributed between two stress pattern types, either with stress always on the stem as in $-a j$ - verbs (e.g., pláka-t' 'to cry' - pláč- $u$ 'non-past, 1sg.' or with stress that changes position in the non-past forms (e.g., v'azá-t' 'to bind' - v'až-ú 'non-past, 1sg.' - v'áž-eř 'non-past, 2sg.' From this, it is not clear how stress could influence palatalization pattern productivity but this question should be addressed in future studies.

\section{Implications for child language acquisition}

According to data from Russian child language, the acquisition of stem allomorphic variation is preceded by a period of verb overregularizations (Ceytlin 2009). In early stages of language acquisition (3-4 year old) children seem to avoid allomorphy in two ways. Importantly, in both cases, there is a tendency to maintain paradigm uniformity. The processes involve either 1) levelling by analogy with other forms in the paradigm or 2) applying the so-called " $\mathrm{j}$ correlation" model (Ceytlin 2009), which consists of inserting a yod $(/ \mathrm{j} /)^{6}$ in the intervocalic position at the stem/inflection boundary of the most productive Russian verb class (e.g., čita- $t^{\prime}$ 'past'/čitaj-u 'non-past' 'read'). The former is illustrated by children productions such as $m o[\check{z}] u t$ 'non-past, 3pl.' instead of $m o[\mathrm{~g}] u t$ based on $m o[\check{z}]-e t$ 'non-past, 3sg.' 'be able' or $x o[\check{c}] u t$ 'non-past, 3pl.' instead of $x o$ [t'] at based on $x o$ [č ]-et 'non-past, 3sg.' 'wish'. Alternations of the type presented in $-i$ - verbs (e.g., $x o d$-it' 'to walk' - $x o$ [ž]- $u$ 'walk-non-past, 1 sg.') are also eliminated by analogy of the $1 \mathrm{sg}$. non-past form to other forms in the paradigm: children produce $x o\left[\mathrm{~d}^{\prime}\right]-u$ instead of $x o[z ̌]-u$ in the $1 \mathrm{sg}$. non-past. The latter, the j-correlation model, applies to $-a$ - stem verbs. For example, children will not palatalize consonants in verb that should be palatalized pla[k]aj-u 'non-past, 1sg.' instead of pla[č $]-u$ 'cry' or $s p r j a[\mathrm{t}] a j-u s$ ' 'nonpast, 1sg.' instead of sprja[č]-us' 'hide'. This process is transparent and does not involve any consonant alternations. It seems to be the preferred pattern used by children in early stages of language acquisition (3-4 years). Thus, the two types of allomorphy discussed in this paper tend to be eliminated in Russian child language through these two processes of overregularization.

\footnotetext{
${ }^{6}$ In their study on Russian verbal morphology, Gor and Chernigovskaya (2001) call this pattern “j-deletion”.
} 
In order to gain a better understanding of acquisition of stem allomorphy involving palatalization, it is crucial to know how palatalization is processed by adult speakers of Russian. Acquiring these alternations appears to be a challenging task for children because they are faced with confusing data in the input. This suggests that word-specific learning should take place for these forms in the initial stages of Russian acquisition. If so, palatalization errors are expected to occur in the form of overregularization of one of the stems.

\section{Conclusion}

In conclusion, the same morphonological alternation, i.e. palatalization, that results in verb stem allomorphy in Russian has apparently different representations and is differently processed in the adult language, depending on the lexical status of the verb and its verb conjugation class. Palatalization seems to be less productive (or even unproductive) in a sub-group of verbs with past/non-past stem allomorphy (corresponding to - $a$-verbs), while it is more prevalent but not completely productive in the $1 \mathrm{sg}$. non-past of a sub-group of 2 nd conjugation $-i$ - stem verbs. Among the factors that influence the productivity patterns discussed in this paper are the allomorph distribution within a verb paradigm, verb class productivity and verb class interactions within the whole Russian verb system. It seems that the influence of verb class on palatalization is greater than the pattern of allomorph relations in a verb paradigm. As was mentioned, both types of allomorphy are subject to overregularization in child language. The study on how different stem allomorphy types involving palatalization are acquired in Russian is ongoing.

\section{References:}

Anderson, Stephen R. (1992) A-Morphous Morphology. Cambridge: Cambridge University Press.

Berko, Jean. (1958) “The child's learning of English morphology”. Word 14: 150-177.

Bernštejn, Samuil B. (1974) Očerk sravnitel'noj grammatiki slavjanskix jazykov. Čeredovanija. Imennye osnovy. Moskva: Nauka.

Bertram, Raymond, Robert Schreuder, and R. Harald Baayen. (2000) “The balance of storage and computation in morphological processing: The role of word formation type, affixal homonymy and productivity". Journal of Experimental Psychology: Learning, Memory, and Cognition 26(2): 489-511.

Bybee, Joan. (1995) "Regular morphology and the lexicon". Language and Cognitive Processes 10(5): 425-455.

Bybee, Joan. (2001) Phonology and language use. Cambridge: Cambridge University Press.

Ceytlin, Stella N. (2009) Očerki po slovoobrazovaniju i formoobrazovaniju v detskoj reči. Moskva: Znak (Studia Philologica).

Chomsky, Noam and Morris Halle. (1968) The sound pattern of English. New York: Harper \& Row.

Daland, Robert, Andrea D. Sims and Janet Pierrehumbert. (2007) "Much ado about nothing: A social network model of Russian paradigmatic gaps". Proceedings of the 45th Annual Meeting of the Association of Computational Linguistics, Prague: Association of Computational Linguistics, 936-943. 
Hay, Jennifer B. and R. Harald Baayen. (2005) "Shifting paradigms: gradient structure in morphology". TRENDS in Cognitive Sciences 9 (7): 342-348.

Gor, Kira and Tatiana Chernigovskaya. (2001) "Rules in the processing of Russian verbal morphology”. In Gerhild Zybatow, Uwe Junghanns, Grit Melhorn and Luka Szucsich (eds.), Current issues in formal Slavic linguistics. Frankfurt am Main: Peter Lang, 528535.

Guskova, Maria and Michael Becker. (2013) "Nonce words show that Russian yer alternations are governed by the grammar". Natural Language and Linguistic Theory 31:735-765.

Jakobson, Roman. (1948) "Russian conjugation" Word 4: 155-167.

Marcus, Gary F., Steven Pinker, Michael Ullman, Michelle Hollander, T. John Rosen, Fei Xu, and Harald Clahsen. (1992) Overregularization in language acquisition. Monographs of the Society for Research in Child Development, 57(4).

Pinker, Steven. (1999) Words and rules. New York: Basic Books.

Pierrehumbert, Janet B. (2006) "The statistical basis of an unnatural alternation". In L. Goldstein, D.H. Whalen, and C. Best (eds), Laboratory Phonology VIII, Varieties of Phonological Competence. Berlin: Mouton de Gruyter, 81-107.

Royle, Phaedra, Beritognolo, Gustavo and Eve Bergeron. (2012) "Regularity, sub-regularity and irregularity in French acquisition". In J. van der Auwera, T. Stolz, A. Urdze and H. Otsuka (Eds.), Irregularity in morphology (and beyond). Berlin: Akademie Verlag, 227-250.

Slioussar, Natalia. (2003) Psixolingvističeskoe issledovanie struktury mental'nogo leksikona na materiale russkix glagolov. MA Thesis, Saint Petersburg State University, Department of General Linguistics (Unpublished).

Švedova, Natalia Ju. (ed.). (1980) Russkaja grammatika. Moskva: Nauka.

Townsend, Charles E. (1975) Russian word formation. Cambridge, MA:Slavica.

Zalizniak, Andrej A. (1977, 2003) Grammatičeskij slovar' russkogo jazyka. Moskva: Russkie slovari.

Zalizniak, Andrej A. (1985) Ot praslavianskoj akcentuacii k russkoj. Moskva: Nauka.

Zamuner, Tania S., Annemarie Kerkhoff and Paula Fikkert. (2012) "Phonotactics and morphophonology in early child language: Evidence from Dutch". Applied Psycholinguistics 33: 481-499. 


\section{APPENDIX}

a). List of novel stimuli items for the palatalization task:

1. fykat'

2. botat'

3. muxat'

4. fuzat'

5. bukat'

6. brysat'

7. smexat'

8. fetat'

9. mosat'

10. snekat'

11. bryzat'

12. trizat'

13. šrekat'

14. xrutat'

15. loxat'

16. dvasat'

b) List of novel stimuli items for the de-palatalization task:

1. fyču

2. fužu

3. bryšu

4. sneču

5. lošu

6. xruču

7. dvašu

8. boču

9. trižu

10. šreču

11. bruču

12. mošu

13. feču

14. bryžu

15. mušu

16. paču 